\title{
Health-related quality of life assessment among patients with inflammatory bowel diseases after surgery - review
}

\author{
Grażyna Bączyk ${ }^{1}$, Dorota Formanowicz², tukasz Gmerek$^{3}$, Piotr Krokowicz ${ }^{3}$ \\ ${ }^{1}$ Department of Nursing Practise, Faculty of Health Sciences, Poznan University of Medical Sciences, Poznan, Poland \\ 2Department of Clinical Biochemistry and Laboratory Medicine, Poznan University of Medical Sciences, Poznan, Poland \\ ${ }^{3}$ Department of General and Colorectal Surgery, Faculty of Health Sciences, Poznan University of Medical Sciences, Poznan, \\ Poland
}

Key words: inflammatory bowel disease, health-related quality of life, surgery, review.

\begin{abstract}
Address for correspondence: Grażyna Bączyk PhD, Department of Nursing Practice, Faculty of Health Sciences, Poznan University of Medical Sciences, 79 Dąbrowskiego St, 60-529 Poznan, Poland, phone: +48 6185468 64, fax: +48 618546864 , e-mail: gbaczyk@ump.edu.pl
\end{abstract}

\begin{abstract}
Aim of the work was to review systematically the published literature addressing whether quality of life (QoL) and health-related QoL (HRQoL) are influenced by surgery among patients with inflammatory bowel disease (IBD). Electronic databases and published articles were searched to identify relevant studies published in the years 1990-2015. Then, a multistep selection was undertaken to identify articles that met specific selection criteria, such us specific key-words (IBD, HRQoL, ulcerative colitis (UC), Crohn's disease (CD), and surgery), and the population was assessed (studies concerning patients < 18 years old were excluded). The review included 27 studies that were evaluated in the context of the influence of surgery on QoL and HRQoL. Concluding, with the increase in the incidence of IBD, monitoring of QoL is an important indicator of the health effects at each stage of the surgical treatment.
\end{abstract}

\section{Introduction}

Ulcerative colitis (UC) and Crohn's disease (CD) are inflammatory bowel diseases (IBD), the cause of which are immunological disorders, leading to gastrointestinal injury. Both UC and CD are often related in terms of clinical symptoms with periods of remission and of active intestinal inflammation (abdominal pain, diarrhoea, bloody diarrhoea, or pus and mucus per rectum) that may require hospitalisation [1, 2]. Treatment of IBD consists of anti-inflammatory and immunosuppressive drugs including biological therapy with tumor necrosis factor $\alpha$ (TNF- $\alpha$ ) inhibitors for inducing and maintaining remission $[3,4]$.

Generally, IBD is more common in industrialised than rather in agricultural countries, with the highest incidence rates reported the in the United Kingdom [5], Scandinavia [6], and North America [7, 8]. In Europe alone more than three million people are estimated to be affected by IBD. Eastern Europe has recently reported rising incidence rates, so their mean IBD occurrence is comparable to that of Western Europe [9]. Data on the epidemiology of IBD in Eastern Europe, including disease course and treatment choices, are limited by the small number of studies available [10]. There is a continuing trend toward increasing incidence and prevalence of IBD across Asia (particularly in East Asia). While this is occurring among developing nations, it is also being seen in Japan, a socio-economically advanced country [11]. Moreover, the incidence of UC has been increasing in Western countries since the Second World War.

The incidence of CD is less than 1 per 100,000 in Asia and South America, 1-3 per 100,000 in southern Europe and South Africa, 16 per 100,000 in New Zealand and Australia, 14 per 100,000 in Canada, and 7 per 100,000 in the USA (based on data only from Olmsted County, Minnesota).

In developed countries, UC emerged first and then CD followed. In the past 20 years, CD has generally 
overtaken UC in incidence rates. In developing countries in which IBD is emerging, UC is typically more common than CD. For example, in India, there are reports of a UC/CD ratio of $8: 1[11]$.

Inflammatory bowel diseases have a chronic course and cannot be completely cured by pharmacological methods. Even after many years of remission, the disease recurs after some time, resulting in the need to start treatment from the beginning. Therefore, patients with IBD should be under the constant care of a specialist. In addition to pharmacological and dietary treatment the patient requires the constant care of a clinical psychologist. Quite often, patients will require surgery. The objectives of surgical treatment, which originally consisted of mere reduction of fatality and incidence, have evolved over the years to focus on improvement in the quality of life (QoL) [12]. Quality of life is a broad evaluation of human function concerning a variety of domains, and according to the internationally accepted definition it is an individual's perception of their position in life, in the context of the culture and value systems in which they live, in accordance with goals, expectations, standards, and concerns [13]. Outcomes of QoL assessment are important for the development of therapeutic programmes for patients with non-specific IBD requiring surgical treatment. On the other hand, another approach to this issue seems to be even more suitable. It concerns the use of assessment of health-related quality of life (HRQoL), which is a part of QoL. According to the definition of the World Health Organisation (WHO), HRQoL depends on main areas such as physical, mental, and social functioning, as well as the patients' subjective evaluation of their QoL, so it incorporates both objective and subjective aspects. This concept is the most frequently used for studies as well as for evaluation of treatment outcomes [14] and is not as extensive as the QoL evaluation.

To assess the quality of life in patients with IBD, especially for UC patients, disease-specific health-related quality of life questionnaires are the most commonly used. Among them is the Inflammatory Bowel Disease Questionnaire (IBDQ-36) [15], which covers the assessment for general QoL and in individual domains: bowel symptoms - amount of stools, presence of thin stools and blood in stool, stomach aches, pain of systolic intestines, swelling of the stomach, transiting of gasses, feeling an urge to pass a stool, dirtying underwear, nausea, and stomach complaint; systemic symptoms - tiring out and tiring, level of energy, bad physical and mental state, sleeping disorders, and weight loss; emotional function - impatience, anxiety connected with necessity of surgical treatment, anxiety connected with the impossibility of finding a toilet, depression, relaxation, confusion because of intestinal problems, anger, slight annoyance (or crying), oversensitivity, depression, lack of understanding, and satisfaction from one's life; social function - absence from work or school, the need to cancel sports matches, the impossibility to practise sport and to spend the free time in an enjoyable way, avoiding sports matches and places where there is no close access to a toilet, and limited sexual activity. Lower scores indicate lower QoL.

The next questionnaire is the Cleveland Global Quality of Life Instrument (CGQLI), which was developed by Fazio et al. [16] to study QoL among UC patients after proctocolectomy with ileal pouch-anal anastomosis (IPAA). This scale assessment HRQoL contains three domains: current QoL, quality of health, and energy level. Overall score is calculated from these three domains. The Gastrointestinal QoL Index (GIQLI) also measures HRQoL and consists of 36 questions focusing on gastrointestinal disorders. It consists of five dimensions: physical function, emotional status, social function, gastrointestinal symptoms, and distress from medical treatment [17].

On the other hand, the Colorectal Functional Outcomes Questionnaire (COREFO) has been used to study QoL in patients with UC. It consists of 27 questions combined in five multi-item scales - faecal incontinence, social impact, stool frequency, stool related aspects, and the need for anti-diarrhoea medication. The scoring is from 0 to 100 , with higher scores indicating more bowel-function problems [18]. The Faecal Incontinence Quality of Life Scale (FIQLS) by Rockwood et al. [19] was used as a "symptom-specific score" to assess the effect of faecal incontinence on QoL in UC patients after IPAA. This scale consists of 29 questions in four domains: lifestyle, coping/behaviour, depression/ self-perception, and embarrassment. The Short Form 36 scale (SF-36) has been used to study generic QoL [20]. This scale consists of 36 questions evaluating QoL in eight domains: physical functioning, social functioning, role limitations due to physical and emotional problems, mental health, energy and vitality, body pain, and general health perception.

The increasing number of studies focusing on $\mathrm{QoL}$ and HRQoL in patients with IBD combined with the increasing number of performed operations prompted us to investigate the existing literature to find a reliable influence of surgery on QoL and HRQoL in patients suffering from UC or CD.

This is an overview of the available literature on QoL and HRQoL in patients with IBD, with particular attention paid to the effects of surgical treatment. We analysed the effects of various surgical therapies on QoL and HRQoL in patients suffering from IBD. On the 
other hand, it should be underlined that the instruments (scales, questionnaires) that were used by various researchers in their studies might be individually inadequate. Thus, to have a deeper insight into this issue and to find a real correlation between surgical therapies, QoL, and HRQoL, we integrated available data meeting our input criteria to provide an accurate evaluation of the QoL and HRQoL in patients with IBD after surgery.

\section{Methods}

To identify potential articles to be included in this review, the MEDLINE, CINHAL, and Pub Med bases were searched for all abstracted articles from the years 1990 to 2015 . The following subjects were taken into account: quality of life (MESH), health-related quality of life (MESH), inflammatory bowel disease (MESH), ulcerative colitis (MESH), Crohn's disease (MESH), and surgery (MESH). We also studied the reference list of the relevant articles for titles that included the words: quality of life and surgery.

The search was limited to English-language, adult population, and full-text publications. We excluded articles that presented studies related to the validation of the questionnaire and articles concerning patients with unclear IBD diagnosis or lack of surgical treatment.

\section{Results}

Articles selected during the initial search: 30,0884. Articles selected based on title and abstract: 4317. Articles selected on the basis of the full text: 138 . Articles that meet specified criteria: 28 .

The obtained results are summarised in the Table I. This table contains information about the purpose of research, the study group, the used scales, the results obtained, and the conclusions. To facilitate the understanding of the presented results, general information about the individual scales is shown below the tables, i.e. number of questions, and the number studied domains (Table I).

\section{Discussion}

Research in the last 25 years has focused on the following aspects:

1. Impact assessment of surgical treatment on quality of life in patients with UC or CD [21-48].

2. Comparisons of the quality of life of patients with regard to the different methods of surgery, pharmacology, and disease activity $[21,24,26,30,32-34$, 37-39, 41, 43, 46].

3. Assessment of quality of life before and after surgery and the assessment of the observed changes in qual- ity of life including the time elapsed since surgery [25, 32, 39-41]

4. Determination of the factors affecting the quality of life in the post-operative period [42, 46-48].

5. Assessment of the quality life of patients with UC or $C D$, including the choice of treatment $[23,28,45,46]$. Improvement of HRQoL is the main determinant in decision-making for surgery in patients with UC and CD. Research has shown that surgical interventions positively affect $H R Q o L$ in patients with IBD, and analysis of the majority of studies shows that patients with CD have a poorer HRQoL than patients with UC. Analysed results investigated the short- and longterm effects of surgical therapy for UC and surgical resection for CD on HRQoL. Most of the research concerns the assessment of quality of life before surgery and in the early (and some later) period after surgery $[22,25,32,33,40]$. The HRQoL was lower shortly after surgery than later among UC patients, but for CD patients it appears to improve the quality of life in the immediate postoperative period, but after a longer lapse of time it is comparable to the quality of life before the operation; it follows the natural course of the disease [22].

Surgical resection leads to improved long-term HRQoL, with the exception of patients with chronic disease process and active disease, especially for patients with CD. These factors should be considered before surgery is indicated in CD [25]. Surgical advances, such as the introduction of minimally invasive surgeries, intestinal-sparing strictureplasties, and the adaptation of different approaches to anaesthesia in patients undergoing CD surgeries. These techniques hold the promise of improving HRQoL. Results after strictureplasty are comparable to those after resection in terms of complications, recurrence, and quality of life in the treatment of small bowel strictures in $C D[22,23,27]$.

Surgical treatment of patients with CD the alleviation of the symptoms. It is therefore needed to assess the effect of surgical treatment on the quality of life of these patients. Studies have shown a low QoL and highlight a significant influence of intestinal ailments as the main determinant of the perception of the QoL of patients with IBD $[32,46]$.

In the study by Casellas, a comparison of HRQoL between surgical and pharmacological treatment patients with CD patients showed that HRQoL is impaired in active $C D$ and improves during remission regardless of whether it had been achieved medically or surgically [26].

The analysed studies were conducted using specific questionnaires (disease-specific scales) and general (global scales) for the assessment of quality of life. Most studies used disease-specific scales: the Gastro- 
Table I. Health-Related Quality of Life in UC and CD after surgery

\begin{tabular}{|c|c|c|c|}
\hline \multirow{2}{*}{$\begin{array}{l}\text { Study } \\
\text { [reference no.] }\end{array}$} & Aim of the study & \multirow[t]{2}{*}{ HRQoL scale } & \multirow[t]{2}{*}{ Results/conclusions } \\
\hline & Characteristics of the study group & & \\
\hline \multirow[t]{2}{*}{$\begin{array}{l}\text { Sagar et al. } \\
(1993)[21]\end{array}$} & $\begin{array}{c}\text { Comparison of the QoL between patients } \\
\text { with UC after restorative proctocolectomy } \\
\text { and patients with UC on long-term medical } \\
\text { treatment }\end{array}$ & \multirow[t]{2}{*}{$\begin{array}{l}\text { Öresland } \\
\text { scale }^{12} \\
\text { HADS }^{9}\end{array}$} & \multirow[t]{2}{*}{$\begin{array}{l}\text { HRQOL after IPAA was no worse than that } \\
\text { of patients with UC on medical treatment }\end{array}$} \\
\hline & $\begin{array}{l}103 \text { patients after restorative proctocolectomy; } \\
95 \text { patients with UC on medical treatment }\end{array}$ & & \\
\hline \multirow[t]{2}{*}{$\begin{array}{l}\text { Yazdanpanah et al. } \\
\text { (1997) [22] }\end{array}$} & $\begin{array}{l}\text { Evaluate prospectively the impact of surgery on } \\
\text { HRQOL in patients operated on for CD. } \\
\text { HRQoL was assessed immediately preoperatively } \\
\text { and } 3 \text { months postoperatively }\end{array}$ & \multirow[t]{2}{*}{$\begin{array}{l}\text { SF-36 }{ }^{17} \\
\text { RFIPC }^{16}\end{array}$} & \multirow{2}{*}{$\begin{array}{l}\text { HRQOL was improved postoperatively com- } \\
\text { pared with the immediate preoperative status } \\
\text { in almost all scales. Patients' concerns and } \\
\text { worries decreased after surgery. However, there } \\
\text { was no decreased in the problems associated } \\
\text { with: having an ileostomy bag, having surgery, } \\
\text { energy level, uncertainty of the disease, and } \\
\text { pain or suffering }\end{array}$} \\
\hline & $\begin{array}{l}\text { CD patients ( } 14 \text { women, } 12 \text { men; median age } \\
28.5 \text { years) who have undergone an elective } \\
\text { ileocolonic resection }(n=26)\end{array}$ & & \\
\hline \multirow[t]{2}{*}{$\begin{array}{l}\text { Thirlby et al. } \\
\text { (1998) [23] }\end{array}$} & $\begin{array}{l}\text { Measure the effect of surgical resection on } \\
\text { quality of life in patients with CD and UC. } \\
\text { CD patients underwent resection with } \\
\text { or without strictureplasty for intractable } \\
\text { disease; } 3 \text { UC patients underwent ileo } \\
\text { pouch-anal anastomoses with ileoanal } \\
\text { reservoir (preoperatively and after } 3 \text { months } \\
\text { postoperatively) }\end{array}$ & \multirow[t]{2}{*}{$\mathrm{HSQ}^{10}$} & \multirow[t]{2}{*}{$\begin{array}{l}\text { Preoperative measures of HRQoL of the pa- } \\
\text { tients were low. Postoperatively, after } 3 \text { months, } \\
\text { HRQoL measures improved significantly } \\
(p<0.05) \text { in CD and UC (scores equal to the } \\
\text { general population in most scales) }\end{array}$} \\
\hline & CD patients $(n=36)$ and UC patients $(n=27)$ & & \\
\hline \multirow[t]{2}{*}{$\begin{array}{l}\text { Cohen et al. } \\
\text { (1999) [24] }\end{array}$} & $\begin{array}{l}\text { This is the first study of QoL comparing such } \\
\text { patients with UC treated with CSA with those } \\
\text { treated surgically with colectomy }\end{array}$ & \multirow{2}{*}{$\begin{array}{l}\text { IBDQ }^{11} \\
\text { VAS }^{21} \\
\text { Öresland } \\
\text { Scale }\end{array}$} & \multirow[t]{2}{*}{$\begin{array}{c}\text { Patients with severe steroid-refractory UC } \\
\text { treated with CSA had similar HRQoL compared } \\
\text { with colectomy patients }\end{array}$} \\
\hline & 18 CSA-treated patients and 46 surgical patients & & \\
\hline \multirow[t]{2}{*}{$\begin{array}{l}\text { Tillinger et al. } \\
\text { (1999) [25] }\end{array}$} & $\begin{array}{c}\text { Examination of short- vs. long-term effects of } \\
\text { surgical resection for } C D \text { on } \mathrm{HRQOL}\end{array}$ & \multirow{2}{*}{$\begin{array}{l}\mathrm{CDAl}^{4} \\
\mathrm{TTO}^{20} \\
\mathrm{RFIPC}^{16}\end{array}$} & \multirow{2}{*}{$\begin{array}{l}\text { HRQOL was significantly improved in all patients } \\
3 \text { and } 6 \text { months post surgical resection. } \\
12 \text { patients had also significantly improved } \\
\text { HRQoL after } 24 \text { months (except for the } 4 \text { patients } \\
\text { with chronic active disease). CDAI decreased } \\
\text { significantly after operation, and } \\
10 \text { patients remained in remission for } 24 \text { months. } \\
\text { Two patients had postoperative relapses }\end{array}$} \\
\hline & $\begin{array}{c}\text { CD patients } 1 \text { week before surgery included in } \\
\text { the study and } 3,6 \text {, and } 24 \text { months after surgical } \\
\text { resection }(n=16)\end{array}$ & & \\
\hline \multirow[t]{2}{*}{$\begin{array}{l}\text { Casellas et al. } \\
(2000)[26]\end{array}$} & $\begin{array}{c}\text { Assessment of whether surgical treatment } \\
\text { of CD patients modifies HRQOL, and compared } \\
\text { with inactive CD patients, active CD patients, } \\
\text { or healthy controls }\end{array}$ & \multirow[t]{2}{*}{$\begin{array}{l}\text { EuroQol } \\
\mid \mathrm{BDQ}^{11} \\
\mathrm{PGWB|}^{14}\end{array}$} & \multirow[t]{2}{*}{$\begin{array}{l}\text { HRQOL is impaired in active CD, and improves } \\
\text { during remission regardless of whether it had } \\
\text { been achieved medically or surgically }\end{array}$} \\
\hline & $\begin{array}{c}\text { First group: } 29 \text { CD patients in remission with } \\
\text { a previous bowel resection. } \\
\text { Second group: } 42 \text { clinically active CD patients. } \\
\text { Third group: } 48 \text { patients with medically-induced } \\
\text { remission. } \\
\text { Control group: } 63 \text { healthy individuals }\end{array}$ & & \\
\hline \multirow[t]{2}{*}{$\begin{array}{l}\text { Broering et al. } \\
(2001)[27]\end{array}$} & $\begin{array}{l}\text { Assessment of the results of strictureplasty and } \\
\text { resection in terms of QoL, surgical recurrence, } \\
\text { and postoperative complications }\end{array}$ & \multirow[t]{2}{*}{$\mathrm{IBDQ}^{11}$} & \multirow{2}{*}{$\begin{array}{l}\text { Results after strictureplasty were comparable to } \\
\text { those after resection (complications, recur- } \\
\text { rence, and QoL in the treatment of small bowel } \\
\text { strictures in } \mathrm{CD} \text { ). In the long term it can be an } \\
\text { advantage for strictureplasty because it pre- } \\
\text { vents the complications of resectional therapy }\end{array}$} \\
\hline & $\begin{array}{l}67 \text { CD patients of the small bowel were analysed } \\
\text { retrospectively. Patients were treated either by } \\
\text { strictureplasty (group A) or resection (group B) }\end{array}$ & & \\
\hline
\end{tabular}


Table I. Cont.

\begin{tabular}{|c|c|c|c|}
\hline \multirow{2}{*}{$\begin{array}{l}\text { Study } \\
\text { [reference no.] }\end{array}$} & Aim of the study & \multirow[t]{2}{*}{ HRQoL scale } & \multirow[t]{2}{*}{ Results/conclusions } \\
\hline & Characteristics of the study group & & \\
\hline \multirow[t]{2}{*}{$\begin{array}{l}\text { Thirlby et al. } \\
\text { (2001) [28] }\end{array}$} & $\begin{array}{l}\text { Assessment of the results of the long term in } \\
\text { patients after surgery for UC patients and for } \\
\text { CD patients (preoperatively and after 3, 6, and } \\
12 \text { months) }\end{array}$ & \multirow[t]{2}{*}{$\mathrm{HSQ}^{10}$} & \multirow{2}{*}{$\begin{array}{l}\text { HRQoL is poor in patients with IBD referred for } \\
\text { possible operation, (with particularly low scores } \\
\text { in the scales of general health - health } \\
\text { perception, role limitations due to physical } \\
\text { health, social functioning, and energy level. } \\
\text { Surgical resection resulted in significant im- } \\
\text { provement in HRQOL (postoperative scores are } \\
\text { virtually equal to the scores for the general } \\
\text { population). Aggressive surgical intervention in } \\
\text { many patients with IBD supports the pro- } \\
\text { spective study of HRQoL by surgeons treating } \\
\text { patients with chronic diseases }\end{array}$} \\
\hline & $\begin{array}{c}\text { CD }(n=56) \text { and UC patients }(n=83) \text {. } \\
\text { CD patients underwent resections with } \\
\text { or without postoperative strictureplasties; } \\
5 \text { patients with UC underwent ileal pouch-anal } \\
\text { anastomoses. The average age of CD patients } \\
\text { was } 41 \text { years (range: } 21-77 \text { years), } 24 \text { men and } \\
32 \text { women. The average age of UC patients was } \\
44 \text { years (range: } 15-75 \text { years), with } 59 \text { men } \\
\text { and } 24 \text { women }\end{array}$ & & \\
\hline \multirow[t]{2}{*}{$\begin{array}{l}\text { Andersson et al. } \\
(2003) \text { [29] }\end{array}$} & $\begin{array}{l}\text { Comparison of HRQoL and psychosocial } \\
\text { conditions among CD patients and the general } \\
\text { population }\end{array}$ & \multirow[t]{2}{*}{$\begin{array}{l}\mathrm{CDAl}^{4} \\
\mathrm{PGWB}^{14} \\
\text { VAS }^{21}\end{array}$} & \multirow{2}{*}{$\begin{array}{l}\text { HRQOL in these patients according to the SF-36 } \\
\text { seems to be more dependent of present symp- } \\
\text { toms than on the type of previous surgery or } \\
\text { the need for immunosuppressive medications } \\
\text { - aggressive disease as well as previous colonic } \\
\text { surgery lacked predictive value. When compar- } \\
\text { ing subgroups of patients the symptom-index } \\
\text { was the strongest predictor of HRQoL after } \\
\text { correction for possible confounders such as } \\
\text { age, gender, duration of disease, concomitant } \\
\text { small bowel involvement, presence of a stoma, } \\
\text { previous colonic surgery, and aggressive } \\
\text { disease (above } 150 \text { score CDAI) }\end{array}$} \\
\hline & $\begin{array}{l}\text { First group: patients with Crohn's proctocolitis, } \\
\qquad \begin{array}{l}n=127 ; \text { median age } 44 \text { years (range: } 18-78) \\
44.1 \% \text { men. }\end{array} \\
\text { The median duration of disease: } 16 \text { (8-25) years. } \\
\text { Control group: } n=266 \text {; median age: } 45 \text { years } \\
\text { (range: } 19-88 \text { years); } 50.7 \% \text { men }\end{array}$ & & \\
\hline \multirow[t]{2}{*}{$\begin{array}{l}\text { Camilleri-Brennan } \\
\text { et al. (2003) [30] }\end{array}$} & $\begin{array}{l}\text { Determination whether in patients suffering } \\
\text { from UC a restorative resection with ileo pouch- } \\
\text { anal formation offers lower morbidity and better } \\
\text { quality of life than a permanent ileostomy }\end{array}$ & \multirow[t]{2}{*}{$\begin{array}{l}\mathrm{BIQ}^{1} \\
\mathrm{IBDQ}^{11} \\
\mathrm{SF}-36^{17}\end{array}$} & \multirow{2}{*}{$\begin{array}{c}\text { There were no significant differences between } \\
\text { the scores of IBDQ and SF- } 36 \text { of the ileo } \\
\text { pouch-anal patients and those of the ileostomy } \\
\text { patients. Perception of body image was better } \\
\text { in the ileo pouch-anal patients than in the } \\
\text { ileostomy patients }\end{array}$} \\
\hline & $\begin{array}{l}19 \text { patients of the pouch and } 19 \text { patients of the } \\
\text { ileostomy. The median times since surgery were } \\
\text { similar: } 41 \text { vs. } 43 \text { months }\end{array}$ & & \\
\hline \multirow[t]{2}{*}{$\begin{array}{l}\text { Carmon et al. } \\
(2003)[31]\end{array}$} & $\begin{array}{l}\text { Evaluation of functional outcome and QoL in } \\
\text { patients undergoing IPAA, assessment of the } \\
\text { correlation between functional outcome and } \\
\text { QoL, and identification of factors influencing } \\
\text { functional outcome and QoL in these patients }\end{array}$ & \multirow[t]{2}{*}{ SF-36 17} & \multirow{2}{*}{$\begin{array}{l}\text { The results were compared with published } \\
\text { norms for the general Israeli population. There } \\
\text { was no significant difference between both of } \\
\text { the groups. Scores slightly but significantly } \\
\text { lower than those of the general population } \\
\text { were recorded in the following scales: vitality, } \\
\text { social functioning, and role-emotional. } \\
\text { Patients with UC after IPAA experienced } \\
\text { excellent QoL and acceptable functional } \\
\text { outcome }\end{array}$} \\
\hline & $\begin{array}{l}99 \text { patients - Israeli population ( } 35: \mathrm{M}, 64: \mathrm{F}) \text {; } \\
\text { median follow-up time was } 4.25 \text { years (range: } \\
3 \text { months to } 11 \text { years) with UC. Surgery was } \\
\text { performed in one stage in } 21 \text { ( } 27.3 \%) \text { patients, } \\
\text { two stages in } 52(67.5 \%) \text { patients, and three } \\
\text { stages in } 4(5.2 \%) \text { patients. The median interval } \\
\text { between the first operation and closure of } \\
\text { ileostomy was } 3 \text { months (range: } 0-17 \text { months) }\end{array}$ & & \\
\hline \multirow[t]{2}{*}{$\begin{array}{l}\text { Scarpa et al. } \\
(2004) \text { [32] }\end{array}$} & $\begin{array}{l}\text { Evaluation of the long-term HRQL among UC } \\
\text { patients and its modifications after } 5 \text {-year } \\
\text { follow-up. Identification of the risk factors for } \\
\text { a worse outcome }\end{array}$ & \multirow[t]{2}{*}{$\mathrm{IBDQ}^{11}$} & \multirow{2}{*}{$\begin{array}{l}\text { RPC patients, after long-term follow-up, had an } \\
\text { HRQoL similar to that of the remission/mild UC } \\
\text { patients. Recently operated patients improved } \\
\text { their QoL mainly because of improved } \\
\text { emotional function. Patients who had been } \\
\text { operated on for a longer time maintained their } \\
\text { HRQoL. } \\
\text { HRQoL was influenced by drugs, stool } \\
\text { frequency, pouchitis, postoperative pelvic } \\
\text { complications, and age at diagnosis }\end{array}$} \\
\hline & $\begin{array}{c}\text { Patients submitted to RPC } \\
(n=36 \text {; mean age: } 40 \pm 11 \text { years, } M: 27) . \\
\quad \text { Ulcerative colitis }(U C) \text { patients } \\
(n=36 ; \text { mean age: } 41 \pm 14 \text { years, } M: 20) . \\
\quad \text { Healthy subjects } \\
(n=36 ; \text { mean age: } 41 \pm 14 \text { years, } M: 20)\end{array}$ & & \\
\hline
\end{tabular}


Table I. Cont.

\begin{tabular}{|c|c|c|c|}
\hline \multirow{2}{*}{$\begin{array}{l}\text { Study } \\
\text { [reference no.] }\end{array}$} & Aim of the study & \multirow[t]{2}{*}{ HRQoL scale } & \multirow[t]{2}{*}{ Results/conclusions } \\
\hline & Characteristics of the study group & & \\
\hline \multirow[t]{2}{*}{$\begin{array}{l}\text { Thaler et al. } \\
\text { (2005) [33] }\end{array}$} & $\begin{array}{l}\text { Assessment of the QoL in patients after } \\
\text { laparoscopic and open surgery: ileocaecal } \\
\text { resection with primary anastomosis for CD } \\
\text { patients }\end{array}$ & \multirow[t]{2}{*}{$\begin{array}{l}\mathrm{GIQLI}^{8} \\
\mathrm{SF}-36^{17}\end{array}$} & \multirow{2}{*}{$\begin{array}{l}\text { QoL is significantly reduced in patients with CD } \\
\text { at long-term follow-up after both laparoscopic } \\
\text { and open surgery. Recurrence is the only factor } \\
\text { adversely affecting QOL of CD patients in } \\
\text { remission irrespective of the operative } \\
\text { technique applied }\end{array}$} \\
\hline & $\begin{array}{c}37 \text { patients with a mean age of } 48.8 \pm 18.4 \text { years } \\
\text { ( } n=23 \text { females and } 14 \text { males) were evaluated } \\
\text { at a mean follow-up of } 42.6 \pm 25.8 \text { months } \\
\text { (minimum of } 8 \text { months). } N=21(57 \%) \text { patients } \\
\text { underwent laparoscopic resection } \\
\text { and } n=16(43 \%) \text { open surgery }\end{array}$ & & \\
\hline \multirow[t]{2}{*}{$\begin{array}{l}\text { Nessar et al. } \\
(2006)[34]\end{array}$} & $\begin{array}{c}\text { Evaluation of long-term outcomes for patients } \\
\text { undergoing Kock continent ileostomy, finding } \\
\text { factors associated with adverse outcomes and } \\
\text { comparison of changes in QoL after removal of } \\
\text { the reservoir }\end{array}$ & \multirow[t]{2}{*}{$\mathrm{CGQL}^{2}$} & \multirow[t]{2}{*}{$\begin{array}{c}\text { QoL for patients with } \mathrm{Cl} \text { was higher on all } \\
\text { scales in comparison with patients who had } \\
\text { the Kock reservoir. } \\
\text { Complications were common among } \mathrm{Cl} \\
\text { patients }\end{array}$} \\
\hline & $\begin{array}{l}\text { Patients with continent ileostomy }(\mathrm{Cl}) \\
(n=181) \text { vs. patients who underwent removal } \\
\text { of the continent ileostomy and conversion to an } \\
\text { end ileostomy (EI) with Kock reservoir }(n=35) ; \\
\text { median patient follow-up } 11 \text { years (range: } 1-27)\end{array}$ & & \\
\hline \multirow[t]{2}{*}{$\begin{array}{l}\text { Scarpa et al. } \\
(2007)[35]\end{array}$} & $\begin{array}{c}\text { Evaluation of long-term health-related quality of } \\
\text { life ( } \mathrm{HRQ} \mathrm{L} \text { ) outcome and its clinical predictors } \\
\text { in } \mathrm{CD} \text { patients who have had ileocolonic } \\
\text { resection }\end{array}$ & \multirow[t]{2}{*}{$\begin{array}{c}\mathrm{CGQL}^{2} \\
\mathrm{CDAl}^{4} \\
\mathrm{PIBDQL}^{13}\end{array}$} & \multirow{2}{*}{$\begin{array}{l}\text { CD patients who have undergone ileocolonic } \\
\text { resection having an apparently normal quality } \\
\text { of life with a good energy level, their long- } \\
\text { term HRQoL is still affected by a significantly } \\
\text { impaired quality of health. The PIBDQL } \\
\text { questionnaire showed significant impairment } \\
\text { of bowel and systemic symptom domains with } \\
\text { important consequences for social functions } \\
\text { and emotional }\end{array}$} \\
\hline & $\begin{array}{l}\text { 97 CD patients, with a mean follow-up of } \\
47.1 \text { months ( } 95 \% \mathrm{Cl}: 40.7-53.5 \text { months) } \\
\text { after ileocolonic resection, were interviewed } \\
\text { by telephone. } \\
\text { Control group: } 69 \text { healthy }\end{array}$ & & \\
\hline \multirow[t]{2}{*}{$\begin{array}{l}\text { Luiz et al. } \\
\text { (2009) [36] }\end{array}$} & $\begin{array}{c}\text { Assessment of the quality of life of UC patients } \\
\text { who have undergone proctocolectomy with } \\
\text { ileal J-pouch-anal anastomosis over } 10 \text { years } \\
\text { ago, ulcerative colitis patients who underwent } \\
\text { proctocolectomy with ileal pouch-anal } \\
\text { anastomosis over ten years before being } \\
\text { included into the study }\end{array}$ & \multirow[t]{2}{*}{$\mathrm{IBDQ}^{11}$} & \multirow[t]{2}{*}{$\begin{array}{l}\text { Most of the studied patients presented a high } \\
\text { score in the QoL questionnaire. The question } \\
\text { pleased and thankful for patients' personal life } \\
\text { received the highest score in the questionnaire. } \\
\text { The possibility of sphincter preservation should } \\
\text { always be considered because patients remain } \\
\text { clinically stable and had a good QoL even after } \\
\text { a long period post-operation }\end{array}$} \\
\hline & $\begin{array}{c}\text { Study group: } n=36, M: 38.9 \% \text {, the average and } \\
\text { median ages were } 45 \text { and } 44 \text { years, respectively, } \\
\text { while ages ranged from } 28 \text { to } 64 \text { years old }\end{array}$ & & \\
\hline \multirow[t]{2}{*}{$\begin{array}{l}\text { Wade et al. } \\
\text { (2009) [37] }\end{array}$} & $\begin{array}{l}\text { Determination of whether there are any } \\
\text { differences in QoL between patients who had } \\
\text { the J pouch and those who had the W pouch }\end{array}$ & \multirow[t]{2}{*}{$\mathrm{RFIPC}^{16}$} & \multirow{2}{*}{$\begin{array}{l}\text { The J-pouch configuration is technically less } \\
\text { demanding. It results in similar QoL when } \\
\text { compared to the W pouch. The J pouch should } \\
\text { be the preferred choice }\end{array}$} \\
\hline & 30 patients received a J-pouch and 19 a W-pouch & & \\
\hline \multirow[t]{2}{*}{$\begin{array}{l}\text { da Luz Moreira } \\
\text { et al. (2010) [38] }\end{array}$} & $\begin{array}{l}\text { Determination of the fate of the rectum, } \\
\text { functional results, and QoL after IRA in UC }\end{array}$ & \multirow[t]{2}{*}{$\mathrm{CGQL}^{2}$} & \multirow{2}{*}{$\begin{array}{c}\text { Patients with IRA had fewer bowel movements, } \\
\text { less night-time seepage, and increased urgency } \\
\text { in comparison with patients with IPAA. QoL was } \\
\text { similar in both of the studied groups' methods; } \\
\text { IRA is inferior to IPAA because of dietary and } \\
\text { work restrictions }\end{array}$} \\
\hline & $\begin{array}{l}22 \text { patients suffering from UC with IRA vs. } \\
66 \text { IPA, median follow-up was } 9 \text { years } \\
\text { (range: } 1-36 \text { years) }\end{array}$ & & \\
\hline
\end{tabular}


Table I. Cont.

\begin{tabular}{|c|c|c|c|}
\hline \multirow{2}{*}{$\begin{array}{l}\text { Study } \\
\text { [reference no.] }\end{array}$} & Aim of the study & \multirow[t]{2}{*}{ HRQoL scale } & \multirow[t]{2}{*}{ Results/conclusions } \\
\hline & Characteristics of the study group & & \\
\hline \multirow[t]{2}{*}{$\begin{array}{l}\text { Somashekar et al. } \\
\text { (2010) [39] }\end{array}$} & $\begin{array}{l}\text { Assessment of the functional outcome and QoL } \\
\text { after sphincter-saving operations for UC among } \\
\text { Indian patients }\end{array}$ & \multirow{2}{*}{$\begin{array}{l}\text {; } \\
\\
\\
\end{array}$} & \multirow{2}{*}{$\begin{array}{c}\text { The mean preoperative CGQL was significantly } \\
\text { lower in IPAA patients in comparison with the } \\
\text { permanent ileostomy patients. After the } \\
\text { procedure it improved, but the magnitude } \\
\text { of change was greater among patients } \\
\text { undergoing IPAA }\end{array}$} \\
\hline & $\begin{array}{l}31 \text { Indian (M: 20, F: 11, mean age: } 38 \text {, range: } \\
\text { 20-62 years) patients with UC after restorative } \\
\text { proctocolectomy followed-up for } 4-6 \text { years; all } \\
\text { of these patients had a hand-sewn J-pouch IPAA; } \\
6 \text { Indian (M: 4, F: 2, mean age: } 45 \text {, range: } 36-52 \\
\text { years) patients with UC within } 6 \text { months of the } \\
\text { subtotal colectomy had not undergone J-pouch } \\
\text { IPAA, and thus had permanent ileostomy }\end{array}$ & & \\
\hline \multirow[t]{2}{*}{$\begin{array}{l}\text { Røkke et al. } \\
(2011)[40]\end{array}$} & $\begin{array}{c}\text { Evaluation of the early and long-term surgical } \\
\text { and functional results of IPAA in patients with } \\
\text { intractable UC }\end{array}$ & \multirow[b]{2}{*}{ ly } & \multirow{2}{*}{$\begin{array}{l}\text { The functional results in the early follow-up } \\
\text { (1993) were remarkably similar to the results } \\
9 \text { years later (2002), with no significant } \\
\text { differences in any of the questions. These } \\
\text { findings indicate that the results after an } \\
\text { "adaption period" will remain unchanged }\end{array}$} \\
\hline & $\begin{array}{c}134 \text { consecutive Norwegian patients ( } 77 \text { men } \\
(57.5 \%) \text {, and } 57 \text { women }(42.5 \%) \text {, mean age: } 42.8 \\
\text { years (range: } 17-72 \text { years)), with UC treated with } \\
\text { restorative proctocolectomy and IPAA. Follow-up } \\
7.4 \text { years after } W \text {-ileal pouch ( } n=9 \text { ); J-ileal pouch } \\
\text { construction ( } n=125) \text {. In the first } \\
44 \text { patients, two follow-ups were performed: early } \\
\text { follow-up was } 2.5 \text { years (range: } 0.8-6.7 \text { years) } \\
\text { and late follow-up ( } 9 \text { years later) was } 11.5 \text { years } \\
\text { (range: } 8.2-19.2 \text { years) }\end{array}$ & & \\
\hline \multirow[t]{2}{*}{$\begin{array}{l}\text { Heikens et al. } \\
(2012)[41]\end{array}$} & $\begin{array}{l}\text { Evaluation of the QoL and health status after } \\
\text { IPAA in UC patients and comparison of the } \\
\text { QoL between reference data from a healthy } \\
\text { population }\end{array}$ & \multirow[t]{2}{*}{$\begin{array}{l}\text { RAND-36 } \\
\text { WHOQOL-100 }\end{array}$} & \multirow{2}{*}{$\begin{array}{l}\text { QoL increased after IPAA and reached levels } \\
\text { comparable with those of healthy reference } \\
\text { population in the majority of domains and } \\
\text { dimensions. QoL was restored first after IPAA, } \\
\text { followed by health status }\end{array}$} \\
\hline & $\begin{array}{l}30 \text { patients after IPAA (J-pouch) (M: } 12) . \\
\text { Evaluation: before and after operation: } 6,12,24 \text {, } \\
\qquad 36 \text { months }\end{array}$ & & \\
\hline \multirow[t]{2}{*}{$\begin{array}{l}\text { de Tilio et al. } \\
\text { (2013) [42] }\end{array}$} & $\begin{array}{c}\text { Evaluation of QoL in patients with IPAA for UC } \\
\text { after at least } 1 \text { year postoperatively }\end{array}$ & \multirow[t]{2}{*}{$\mathrm{IBDQ}^{11}$} & \multirow{2}{*}{$\begin{array}{l}\text { In all domains assessed, patients with IPAA } \\
\text { for UC had QoL classified as regular. lleostomy } \\
\text { and lack of professional activity negatively } \\
\text { influenced QoL. There was a tendency to lower } \\
\text { scores in elderly patients }\end{array}$} \\
\hline & $\begin{array}{c}\text { Patients }(n=31) \text {, mean age: } 46.4 \text { years, females } \\
(n=16), \text { postoperative time greater than } \\
10 \text { years in } 71 \% \text { of studied patients }\end{array}$ & & \\
\hline \multirow[t]{2}{*}{$\begin{array}{l}\text { Heikens et al. } \\
\text { (2013) [43] }\end{array}$} & $\begin{array}{l}\text { Evaluation of two surgical methods among } \\
\text { UC patients: restorative surgery after (procto) } \\
\text { colectomy with ileo-neorectal anastomosis } \\
\text { (INRA) and restorative proctocolectomy with } \\
\text { ileal pouch-anal anastomosis (RPC) }\end{array}$ & \multirow[t]{2}{*}{$\begin{array}{l}\text { RAND-36 } \\
\text { WHOQOL-10022 }\end{array}$} & \multirow[t]{2}{*}{$\begin{array}{l}\text { Comparison of INRA and RPC on an intention } \\
\text { to treat basis was not considered to be realistic } \\
\text { because of the high intra-operative conversion } \\
\text { rate and the failures in the INRA group }(n=21)\end{array}$} \\
\hline & $\begin{array}{c}\text { INRA group; } n=71, \text { M: } 29 \\
\text { median age: } 32.3 \text { years, duration } \\
\text { of follow-up } 6.2 \text { years. } \\
\text { RPC group; } n=71, \text { M: } 29 \text {, median age: } 35.1 \text { years, } \\
\text { duration of follow-up } 6.9 \text { years. } \\
\text { During the study a subgroup of successful INRA } \\
\text { patients }(n=50) \text { was created }\end{array}$ & & \\
\hline \multirow[t]{2}{*}{$\begin{array}{l}\text { Salehimarzijarani } \\
\text { et al. (2013) [44] }\end{array}$} & $\begin{array}{l}\text { Evaluation of the QoL in UC patients who } \\
\text { underwent IPAA over } 5 \text { years ago }\end{array}$ & \multirow[t]{2}{*}{$\mathrm{IBDQ}^{11}$} & \multirow{2}{*}{$\begin{array}{l}\text { Long-term QoL was good in the study group. } \\
\text { In the social area, the questions concerning } \\
\text { the working ability and sexual activity received } \\
\text { the lowest and the highest scores, respectively. } \\
\text { Moreover, physical disposition received the } \\
\text { lowest scores, contrary to the satisfaction of } \\
\text { personal life with the highest scores }\end{array}$} \\
\hline & $\begin{array}{c}\text { Iranian patients with UC }(n=39) \text { average age } \\
37 \text { (range: } 18-63 \text { years), after IPAA, categorised } \\
\text { into two different age groups: older }(25.6 \%) \text { and } \\
\text { younger }(74.4 \%) \text { than } 45 \text { years }\end{array}$ & & \\
\hline
\end{tabular}


Table I. Cont.

\begin{tabular}{|c|c|c|c|}
\hline \multirow{2}{*}{$\begin{array}{l}\text { Study } \\
\text { [reference no.] }\end{array}$} & Aim of the study & \multirow[t]{2}{*}{ HRQoL scale } & \multirow[t]{2}{*}{ Results/conclusions } \\
\hline & Characteristics of the study group & & \\
\hline \multirow[t]{2}{*}{$\begin{array}{l}\text { Burisch et al. } \\
\text { (2014) [45] }\end{array}$} & $\begin{array}{l}\text { Assessment of the impact of treatment choices } \\
\text { on HRQoL among patients UC and CD, across } \\
\text { Eastern and Western Europe }\end{array}$ & \multirow[t]{2}{*}{$\begin{array}{l}\text { SF-12 }{ }^{18} \\
\text { SIBDQ }^{19}\end{array}$} & \multirow{2}{*}{$\begin{array}{l}\text { Surgical and pharmacological treatment } \\
\text { improved HRQOL during the first year of } \\
\text { disease. Most of the IBD patients in Eastern } \\
\text { and Western Europe had a high perception of } \\
\text { HRQoL according disease-specific scale. Biolog- } \\
\text { ical treatment improved HRQoL in CD patients; } \\
\text { UC patients in need of surgery or biological } \\
\text { therapy had lower perceptions of HRQoL than } \\
\text { other patients }\end{array}$} \\
\hline & $\begin{array}{l}\text { This study was a prospectively collected, } \\
\text { unselected population- based inception cohort } \\
\text { of } 1079 \text { IBD patients, recruited from } 30 \text { medical } \\
\text { centres from Eastern and Western Europe } \\
(n=402 \text { CD patients, } n=575 \text { UC patients, } \\
n=102 \text { IBDU). } \\
74 \text { patients after surgery }\end{array}$ & & \\
\hline $\begin{array}{l}\text { Meijs et al. } \\
\text { (2014) [46] }\end{array}$ & $\begin{array}{l}\text { Comparison of the HRQoL and disability in UC } \\
\text { patients after restorative proctocolectomy with } \\
\text { ileal pouch-anal anastomosis and in remission } \\
\text { with anti-TNF agents - surgery treatment group } \\
\text { (RPC with ICA): } \\
-29 \text { patients (median age: } 42 \text { years, } 48 \% \\
\text { female); the pouch had to be functional for } \\
\geq 1 \text { year, without postoperative complications; } \\
\text { - medically (anti-TNF agents) induced clinical } \\
\text { remission group: } 29 \text { patients (mean age } \\
45 \text { years, } 65 \% \text { female), treated for } \geq 1 \text { year }\end{array}$ & $\begin{array}{l}\text { EORTC }^{5} \\
\text { COREFO }^{3} \\
\text { SF-36 } 6^{17} \\
\text { WPAI:UC }\end{array}$ & $\begin{array}{l}\text { HRQoL and disability outcomes did not differ } \\
\text { among UC patients who were in remission } \\
\text { following treatment with anti-TNF agents or } \\
\text { after proctocolectomy with ileo pouch-anal } \\
\text { anastomosis, except for stool frequency and } \\
\text { anti-diarrhoea medication use, which were } \\
\text { significantly higher in the surgery treatment } \\
\text { group }\end{array}$ \\
\hline \multirow[t]{2}{*}{$\begin{array}{l}\text { Koerdt et al. } \\
\text { (2014) [47] }\end{array}$} & $\begin{array}{l}\text { Comparison of the QoL among patients after } \\
\text { IPAA and healthy controls and identification of } \\
\text { the specific factors that may have detrimental } \\
\text { effects on QoL in IPAA patients }\end{array}$ & \multirow{2}{*}{$\begin{array}{l}\mathrm{CGQL}^{2} \\
\mathrm{GIQLI}^{8} \\
\mathrm{FIQLS}^{7} \\
\mathrm{IBDQ}^{11} \\
\mathrm{SF}-36^{17}\end{array}$} & \multirow[t]{2}{*}{$\begin{array}{l}\text { Overall HRQoL after IPAA was good. However, } \\
\text { high stool frequency, faecal incontinence and } \\
\text { pouchitis were associated with impaired QoL }\end{array}$} \\
\hline & $\begin{array}{l}48 \text { patients (M: } 32) \text {; median age } 38 \text { years; } \\
\text { median follow-up } 57 \text { months after IPAA. } \\
48 \text { matched controls }\end{array}$ & & \\
\hline $\begin{array}{l}\text { Kozłowska et al. } \\
\text { (2014) [48] }\end{array}$ & $\begin{array}{l}35 \text { patients with UC were treated surgically } \\
3 \text { months after surgery }\end{array}$ & $\begin{array}{l}\mathrm{IBDQ}^{11} \\
\mathrm{SF}-36^{17}\end{array}$ & $\begin{array}{l}\text { The objective IBDQ scale showed better quality } \\
\text { of life in UC patients treated surgically than the } \\
\text { subjective SF-36 scale }\end{array}$ \\
\hline
\end{tabular}

${ }^{1} B I Q$ (Body Image questionnaire (BIQ): 19 items: general body satisfaction, assessment of body image satisfaction and dissatisfaction by measuring the degree of discrepancy self-esteem and idealised physical characteristics, and taking into account the valence or physical significance of each of the ideals to the person; ${ }^{2} C G Q L$ (Cleveland Global Quality of Life Instrument): 47 questions; 4 dimensions: medical symptoms, functional performance, social, life. ${ }^{3}$ COREFO (Colorectal Functional Outcomes Questionnaire): 27 questions, 5 dimension: faecal incontinence, social impact, stool frequency, stool related aspects and need for anti-diarrhoea medical use. ${ }^{4} \mathrm{CDAl}$ (Crohn's Disease Activity Index); eight factors: number of liquid or soft stools, abdominal pain, general wellbeing, presence of complications, taking lomotil or opiates for diarrhoea, presence of an abdominal mass, haematocrit, percentage deviation from standard weight. ${ }^{5}$ EORTC (European Organisation for Research and Treatment of Cancer); 6 items: sexual functioning, sexual enjoyment, male sexual problems, female sexual problems, skin (itchy or dry), muscle and joint. ${ }^{6}$ EuroQol: 5 items: 5 dimensions: mobility, personal care, daily activities, pain, anxiety/depression, VAS indicating health status. ${ }^{7} \mathrm{FIQLS}$ (Faecal Incontinence Quality of Life Scale); 29 questions; 4 domains: lifestyle, coping/behaviour, depression/self-perception, embarrassment. ${ }^{8} \mathrm{GIQLI}$ (Gastrointestinal QoL Index): 36 questions 5 dimensions: physical function, emotional status, social function, gastrointestinal symptoms and distress by medical treatment. ${ }^{9}$ HADS (Hospital Anxiety and Depression); 14 questions: 2 dimensions: anxiety, depression. ${ }^{10} \mathrm{HSO}$ (Health Status Questionnaire): 39 questions; 8 dimensions: a general health perception, physical functioning ,physical role limitations (the interference with work by physical health), emotional role limitations (interference with work by emotional problems), social functioning, mental health, bodily pain, and energy/vitality. ${ }^{11} I B D Q 36$ (Inflammatory Bowel Disease Questionnaire-36): 36 questions; 5 dimensions: bowel, systemic, social, emotional, systemic symptoms. ${ }^{12}$ Öresland scale - questions regarding health care utilization and medication use. ${ }^{13}$ PIBDQL (Padova Inflammatory Bowel Diseases): 29 items intestinal symptoms (eight questions; systemic symptoms (seven questions, emotional function (nine questions; social function (five questions). ${ }^{14}$ PGWB (Psychological General well-being): 22 questions: subjective general well-being. ${ }^{15}$ RAND 36 (RAND 36-Item Health Survey): 36 questions; 8 dimensions: physical functioning, bodily pain, role limitations due to physical health problems, role limitations due to personal or emotional problems, general mental health, social functioning, energy/fatigue, general health perceptions. ${ }^{16}$ RFIPC (Rating Form of Inflammatory Bowel Disease Patient Concerns): 25 questions; 4 dimensions: disease, body, interpersonal, sexual. ${ }^{17}$ SF-36 (Short Form 36): 36 questions, 8 dimension: physical functioning, social functioning, role limitations due to physical and emotional problems, mental health, energy and vitality, body pain and general health perception. ${ }^{18}$ SF-12 (Short Form12): 12 questions, 8 dimension: physical functioning, social functioning, role limitations due to physical and emotional problems, mental health, energy and vitality, body pain and general health perception. ${ }^{19}$ Short IBDQ (Short Inflammatory Bowel Disease Questionnaire-12): 10 questions, 4 dimension: bowel, systemic, social, emotional. ${ }^{20}$ TTO (Time Trade-off Technique): questions used to assess the patients' and carers' quality of life, before and after intervention. ${ }^{21} V A S ;$ visual analogue scale for subjective characteristics or attitudes that cannot be directly measured. ${ }^{22}$ WHOOOL-100 (World Health Organization Ouality of Life-100): 100 questions, 5 dimension: role physical, general health, social functioning, mental health, vitality. ${ }^{23}$ WPAl:UC (Work Productivity and Activity Impairment in UC): 6 questions; four items: absenteeism, presenteeism, activity impairment, overall impairment. 
intestinal QoL Index, the Inflammatory Bowel Disease Short Questionnaire, and the Faecal Incontinence Quality of Life Scale. In turn, among the global scales the SF-36, WHOQOL-100, and RAND-36 were used. In the clinical course of IBD mood disorders are common, and therefore in some studies levels of depression and anxiety were examined. Moreover, in the case of $C D$, researched disease activity was determined on the basis of the Crohn's Disease Activity Index (CDAI). The most common surgical treatment choice, particularly in patients with UC, was TP-IPAA total proctocolectomy with ileal pouch-anal anastomosis (with different techniques of creating an ileal pouch - J, W, S) [49].

In should be underlined that in the case of UC the type of surgical procedure is dependent on the patient's clinical status. In case of fulminant UC with signs of massive colonic bleeding, perforation, toxic megacolon, or in the case of heavily malnourished patients receiving long-term immunosuppressive and steroid treatment, the most reasonable choice is total colectomy with end an ileostomy. During this procedure a long rectal stump is usually left in order to be recognised easily during the next operation. Total colectomy without forming anastomosis is reserved only for severe, life-threatening cases of UC, and it is just the first stage of surgical treatment. After the patient's full recovery, which usually takes about one year, the next procedure involves the creation of an ileal pouch. During the next step the rectal stump is removed, and the ileal pouch (J-pouch is preferred) is formed and anastomosed with a rectal cuff using a mechanical circular stapler (CEEA 28 or 31 ). Since the anastomosis is located low in the pelvis (to avoid clinical manifestation of anastomotic leak sometimes) it is necessary to form a loop ileostomy for 3 months. The last step of surgical treatment is reconnection of the alimentary tract, which does not involve a laparotomy but just a small parastomy incision. In most cases of UC the procedure can be performed in two stages: total proctocolectomy with ileo pouch-anal anastomosis and temporary decompressing loop ileostomy and closure of the ileostomy after 3-6 months, depending on the patient's condition [50,51]. A one-stage surgical treatment, reserved for UC patients who are in a good condition, consists of ileal pouch-anal anastomosis without temporary decompressing ileostomy $[47,52]$. Studies have shown that after IPAA the overall HRQoL was good. Additionally, QoL after IPAA and reached, increased levels comparable with a healthy population served as a reference group in the majority of domains $[41,46]$. However, high stool frequency, faecal incontinence, and pouchitis were associated with impaired quality of life $[41,46]$ references the table if you compared the quality of life of patients after IPAA patients with UC patients on medical treatment, HRQoL was at a similar level [21, 46].

The study focused on comparing the quality of life between patients who had the J pouch and those who had the in the pouch, taking into account the different methods of surgical treatment [37]. Based on the obtained results demonstrated similar QoL compared W-pouch with the J-pouch. However, the J-pouch should be the preferred method of choice. There were no significant differences between HRQoL of the ileo pouch-anal patients and those of the ileostomy patients. Perception of body image was better in the ileo pouch-anal patients than among the ileostomy patients [30]. Both total proctocolectomy with ileostomy and IPAA appear to be equivalent in terms of overall health-related quality of life. Most patients were satisfied with their choice regardless of procedure. Most of the improvement in quality of life after surgery was related to the control of disease-related symptoms [53].

Studies on the assessment of the quality of life before and after surgery, and evaluation of changes in the quality of life including the time elapsed since surgery, indicate that HRQoL was with having good QoL even after a long period post-operation. However, the problems associated with: having ileostomy bag, having surgery, energy level, uncertainty of the disease, and pain or suffering did not decrease [22, 28, 29, 31, 36, 39, 44].

In $\mathrm{CD}$, due to tissues being affected in multiple locations, indications for reconstructive proctocolectomy such as those performed for UC are limited. The procedures need to be as conservative as possible because the disease is chronic and incurable. In most cases, the aim of the surgery is to resect only the damaged parts of the intestine (avoiding unnecessary removal of a margin of normal tissue), to drain intra-abdominal abscesses, and to eliminate fistulas. The most frequent indications for surgical treatment of CD patients include intestinal obstruction due to inflammatory tumour or stricture, perforation with signs of acute peritonitis, intestinal fistulas, acute lower Gl tract haemorrhage, and perianal fistulas. Typically the inflammatory process is localised in the ileocecal region, and right hemicolectomy is the procedure of choice. Consequently, colonoscopy with examination of the terminal ileum is the most sensitive diagnostic tool. In cases of inflammatory strictures or fistulas localised in the small intestine Magnetic Resonance Enterography (MREG) is considered a gold standard. In the case of inflammatory strictures of the small intestine, Heineke-Mikulicz, Finney, Michelassi strictureplasty, or a bypass surgery can be performed, but most surgeons would prefer resection in order not to leave the source of active inflammation in the peritoneal cavity. Perianal manifestation may be the 
first symptom of CD. Perianal fistulas in CD patients are complex and impossible to be cured surgically without the adequate systemic treatment of underlying disease, including also biologic therapy. If the anal sphincter is damaged, it may be recommended that abdomino-perineal rectum resection be performed with a definitive colostomy. Formation of an intestinal fistula is also indicated in cases of intestine perforation with peritonitis and surgical treatment of leaking of previous anastomosis [4, 23, 28].

There are fewer studies on the quality of life of patients with CD than UC patients treated surgically, due to other indices for surgery. Casellas' studies indicate that impaired HRQOL is in active CD, and it improves during remission regardless of whether it had been medically or surgically achieved [26]. On the other hand, Burisch et al. [45] emphasises that pharmacological and surgical treatment improved HRQoL during the first year of the disease.

In conclusion, with the increase in the incidence of IBD monitoring of QoL is an important indicator of the health effects at each stage of the surgical treatment.

\section{Acknowledgments}

We would like to thank John Coueslant for his linguistic consultation of the paper.

\section{Conflict of interest}

The authors declare no conflict of interest.

\section{References}

1. Langholz E, Munkholm P, Davidsen M, Binder V. Course of ulcerative colitis: analysis of changes in disease activity over years. Gastroenterology 1994; 107: 3-11.

2. Munkholm P, Langholz E, Davidsen M, Binder V. Disease activity courses in a regional cohort of Crohn's disease patients. Scand J Gastroenterol 1995; 30: 699-706.

3. Dignass A, Lindsay JO, Sturm A, et al. Second European evidence-based consensus on the diagnosis and management of ulcerative colitis. Part 2: Current management. J Crohns Colitis 2012; 6: 991-1030.

4. Dignass A, Assche G Van, Lindsay JO, et al.; European Crohn's and Colitis Organisation (ECCO). The second European evidence-based Consensus on the diagnosis and management of Crohn's disease: current management. J Crohns Colitis 2010; 4: 28-62.

5. Rubin GP, Hungin a P, Kelly PJ, Ling J. Inflammatory bowel disease: epidemiology and management in an English general practice population. Aliment Pharmacol Ther 2000; 14: 1553-9.

6. Vind I, Riis L, Jess T, et al.; DCCD study group. Increasing incidences of inflammatory bowel disease and decreasing surgery rates in Copenhagen City and County, 2003-2005: a population-based study from the Danish Crohn colitis database. Am J Gastroenterol 2006; 101: 1274-82.
7. Bernstein CN, Wajda A, Svenson LW, et al. The epidemiology of inflammatory bowel disease in Canada: a population-based study. Am J Gastroenterol 2006; 101: 1559-68.

8. Loftus CG, Loftus E V, Harmsen WS, et al. Update on the incidence and prevalence of Crohn's disease and ulcerative colitis in Olmsted County, Minnesota, 1940-2000. Inflamm Bowel Dis 2007; 13: 254-61.

9. Burisch J, Jess T, Martinato M, Lakatos PL; ECCO-EpiCom. The burden of inflammatory bowel disease in Europe. J Crohns Colitis 2013; 7: 322-37.

10. Lakatos PL. Recent trends in the epidemiology of inflammatory bowel diseases: up or down? World J Gastroenterol 2006; 12: 6102-8.

11. World Gastroenterology Organisation Global Guidelines. Inflammatory bowel disease: a global perspective. 2009.

12. McLeop RS, Baxter NN. Quality of life of patients with inflammatory bowel disease after surgery. World J Surg 1998; 22: 375-81.

13. The WHOQOL Group. The World Health Organization Quality of Life assessment (WHOQOL): position paper from the World Health Organization. Soc Sci Med 1995; 41: 1403-9.

14. Schipper H, Clinch JJ, Olweny CLM. Quality of life studies: definitions and conceptual issues. In: Quality of life and pharmacoeconomics in clinical trials. $2^{\text {nd }}$ edn. Spilker B (ed.). Raven, New York Lippincott 1996; 16-8.

15. Irvine EJ. Quality of life - measurement in inflammatory bowel disease. Scand J Gastroenterol 1993; 199: 22-7.

16. Fazio VW, O'Riordain MG, Lavery IC, et al. Long-term functional outcome and quality of life after stapled restorative proctocolectomy. Ann Surg 1999; 230: 575-84.

17. Eypasch E, Williams JI, Wood-Dauphinee S, et al. Gastrointestinal Quality of Life Index: development, validation and application of a new instrument. Br J Surg 1995; 82: 216-22.

18. Bakx R, Sprangers MA, Oort FJ, et al. Development and validation of a colorectal functional outcome questionnaire. Int J Colorectal Dis 2005; 20: 126-36.

19. Rockwood TH, Church JM, Fleshman JW, et al. Fecal incontinence quality of life scale quality of life instrument for patients with fecal incontinence. Dis Colon Rectum 2000; 43: 9-16.

20. Ware JE Jr, Snow KK, Kosiński M, Gandek B. SF-36 health survey: manual and interpretation guide. The Health Institute, New England Medical Center 1994.

21. Sagar PM, Lewis W, Holdsworth PJ, et al. Quality of life after restorative proctocolectomy with a pelvic ileal reservoir compares favorably with that of patients with medically treated colitis. Dis Colon Rectum 1993; 36: 584-92.

22. Yazdanpanah Y, Klein O, Gambiez L, et al. Impact of surgery on quality of life in Crohn's disease. Am J Gastroenterol 1997; 92: 1897-900.

23. Thirlby RC, Land JC, Fenster LF, Lonborg R. Effect of surgery on health-related quality of life in patients with inflammatory bowel disease. A prospective study. Arch Surg 1998; 133: 826-32.

24. Cohen RD, Brodsky AL, Hanauer SB. A comparison of the quality of life in patients with severe ulcerative colitis after total colectomy versus medical treatment with intravenous cyclosporine. Inflamm Bowel Dis 1999; 5: 1-10.

25. Tillinger W, Mittermaier C, Lochs H, Moser G. Health-related quality of life in patients with Crohn's disease: influence of 
surgical operation: a prospective trial. Dig Dis Sci 1999; 44 : 932-8.

26. Casellas F, López-Vivancos J, Badia X, et al. Impact of surgery for Crohn's disease on health-related quality of life. Am J Gastroenterol 2000; 95: 177-82.

27. Broering DC, Eisenberger CF, Koch A, et al. Quality of life after surgical therapy of small bowel stenosis in Crohn's disease. Dig Surg 2001; 18: 124-30.

28. Thirlby RC, Sobrino MA, James B. Randall JB. The long-term benefit of surgery on health-related quality of life in patients with inflammatory bowel disease. Arch Surg 2001; 136: 521-6.

29. Andersson P, Olaison G, Bendtsen P, et al. Health related quality of life in Crohn's proctocolitis does not differ from a general population when in remission. Colorectal Dis 2003; 5: 56-62.

30. Camilleri-Brennan J, Munro A, Steele RJC. Does an ileoanal pouch offer a better quality of life than a permanent ileostomy for patients with ulcerative colitis? J Gastrointest Surg 2003; 7: 814-9.

31. Carmon E, Keidar A, Ravid A, et al. The correlation between quality of life and functional outcome in ulcerative colitis patients after proctocolectomy ileal pouch anal anastomosis. Colorectal Dis 2003, 5: 228-32.

32. Scarpa M, Imerio Angriman I, Ruffolo C, et al. Health-related quality of life after restorative proctocolectomy for ulcerative colitis: long-term results. World J Surg 2004; 28: 124-9.

33. Thaler K, Dinnewitzer A, Oberwalder M, et al. Assessment of long-term quality of life after laparoscopic and open surgery for Crohn's disease. Colorectal Dis 2005; 7: 375-81.

34. Nessar G, Fazio VW, Tekkis P, et al. Long-term outcome and quality of life after continent ileostomy. Dis Colon Rectum 2006; 49: 336-44.

35. Scarpa M, Ruffolo C, D'Incà R, et al. Health-related quality of life after ileocolonic resection for Crohn's disease: long-term results. Inflamm Bowel Dis 2007; 13: 462-9.

36. Luiz A, Meyer M, Teixeira MG, et al. Quality of life in the late follow-up of ulcerative colitis patients submitted to restorative proctocolectomy with sphincter preservation over ten years ago. Clinics 2009; 64: 887-3.

37. Wade AD, Mathiason MA, Brekke EF, Kothari SN. Quality of life after ileoanal pouch: a comparison of J and W pouches. J Gastrointest Surg 2009; 13: 1260-5.

38. da Luz Moreira A, Kiran RP, Lavery I. Clinical outcomes of ileorectal anastomosis for ulcerative colitis. Br J Surg 2010; 97: 65-9.

39. Somashekar U, Gupta S, Soin A, Nundy S. Functional outcome and quality of life following restorative proctocolectomy for ulcerative colitis in Indians. Int J Col Dis 2010; 25: 967-73.

40. Røkke O, Iversen K, Olsen T, et al. Long-term follow-up with evaluation of the surgical and functional results of the ileal pouch reservoir in restorative proctocolectomy for ulcerative colitis. ISRN Gastroenterology 2011; 2011: 625842.

41. Heikens JT, de Vries J, Goosa MR, et al. Quality of life and health status before and after ileal pouch-anal anastomosis for ulcerative colitis. Br J Surg 2012; 99: 263-9.

42. de Tilio M, Arias LB, Camargo MG, et al. Quality of life in patients with ileal pouch for ulcerative colitis. J Coloproctol 2013; 33: 113-7.

43. Heikens JT, de Vries J, de Jong DJ, et al. Evaluation of long-term function, complications, quality of life and health status after restorative proctocolectomy with ileo neo rectal and with ileal pouch anal anastomosis for ulcerative colitis. Colorectal Dis 2013; 15: e323-9.

44. Salehimarzijarani B, Jalaly NY, Dadvar Z, et al. Long-term quality of life after ileal pouch anal restorative proctocolectomy for ulcerative colitis. Indian J Gastroenterol 2013; 32: 49-53.

45. Burisch J, Weimers P, Pedersen N, et al.; EpiCom-group. Health-related quality of life improves during one year of medical and surgical treatment in a European population-based inception cohort of patients with inflammatory bowel disease - an ECCO-EpiCom study. J Cronhs Colitis 2014; 8: 1030-42.

46. Meijs S, Gardenbroek TJ, Sprangers MA, et al. Health-related quality of life and disability in patients with ulcerative colitis and proctocolectomy with ileoanal pouch versus treatment with anti-TNF agents. J Cronhs Colitis 2014; 8: 686-92.

47. Koerdt S, Jehle EC, Kreis ME, Kasparek MS. Quality of life after proctocolectomy and ileal pouch-anal anastomosis in patients with ulcerative colitis. Int J Colorectal Dis 2014; 29: 545-54.

48. Kozłowska K, Bączyk G, Krokowicz P. Quality of life in patients with ulcerative colitis treated surgically. Prz Gastroenterol 2014; 9: 220-6.

49. Ishii K, Kawai K, Hata K, et al. Comparison of functional outcomes of patients who underwent hand-sewn or stapled ileal pouch-anal anastomosis for ulcerative colitis. Int Surg 2015; 7-8: 1169-76.

50. Mclaughlin SD, Clark SK, Tekkis PP, et al. Review article: restorative proctocolectomy, indications, management of complications and follow-up - a guide for gastroenterologists. Aliment Pharmacol Ther 2008, 27: 895-909.

51. McGuire BB, Brannigan AE, O'Connell PR. Ileal pouch-anal anastomosis. Br J Surg 2007; 94: 812-23.

52. Parks AG, Nicholls RJ. Proctocolectomy without ileostomy for ulcerative colitis. Br Med J 1978; 2: 85-8.

53. Murphy PB, Khot Z, Vogt KN, et al. Quality of life after total proctocolectomy with ileostomy or IPAA: a systematic review. Dis Colon Rectum 2015; 58: 899-908.

Received: 18.06 .2016

Accepted: 16.10.2016 